\title{
The properties and structure of $\mathbf{N}$-chloro- $\boldsymbol{N}$-methoxy-4-nitrobenzamide ${ }^{\dagger}$
}

\author{
Vasiliy G. Shtamburg, ${ }^{* a, b}$ Alexander V. Tsygankov, ${ }^{c}$ Oleg V. Shishkin, ${ }^{d}$ Roman I. Zubatyuk, ${ }^{d}$ \\ Boris V. Uspensky, ${ }^{b}$ Victor V. Shtamburg, ${ }^{b}$ Alexander V. Mazepa ${ }^{e}$ and Remir G. Kostyanovsky* $f$ \\ ${ }^{a}$ Ukrainian State Chemico-Technological University, 49038 Dnepropetrovsk, Ukraine. \\ E-mail: stamburg@gmail.com \\ ${ }^{b}$ National Technical University 'Kharkov Polytechnical Institute', 61002 Kharkov, Ukraine. \\ E-mail: polytehnik@gmail.com \\ c State Flight Academy of Ukraine, 25005 Kirovograd, Ukraine.E-mail: geminalsystemsn@gmail.com \\ ' STC 'Institute for Single Crystals', National Academy of Sciences of Ukraine, 61001 Kharkov, Ukraine. \\ E-mail: shishkin@xray.isc.kharkov.com \\ ${ }^{e}$ A. V. Bogatsky Physico-Chemical Institute, National Academy of Sciences of Ukraine, 65080 Odessa, \\ Ukraine.E-mail: almazepa@rambler.ru \\ ${ }^{f}$ N. N. Semenov Institute of Chemical Physics, Russian Academy of Sciences, 119991 Moscow, \\ Russian Federation. Fax: +7 499137 8284; e-mail: kost@ center.chph.ras.ru
}

DOI: 10.1016/j.mencom.2012.05.019

The XRD study of $N$-chloro- $N$-methoxy-4-nitrobenzamide revealed the high pyramidality degree of its amide nitrogen atom in $\mathrm{O}-\mathrm{N}-\mathrm{Cl}$ moiety. $N$-Chloro- $N$-methoxy-4-nitrobenzamide reacts with AcONa in MeCN selectively forming $N$-acetoxy- $N$-methoxy-4-nitrobenzamide, whereas its methanolysis in the presence of AcONa yields $N, N^{\prime}$-bis(4-nitrobenzoyl)- $N, N^{\prime}$-dimethoxyhydrazine.

As it was shown by S. A. Glover et al. ${ }^{2-10} N$-X-N-alkoxycarboxamides $[\mathrm{X}=\mathrm{OC}(\mathrm{O}) \mathrm{R}$, OAlk, $\mathrm{Cl}]$ represent a new unusual family of amides, or anomeric amides. The presence of two strongly electronegative substituents with lone electron pairs (Lp) should effect the pyramidality of the amide nitrogen atom which should be $s p^{3}$ hybridized. ${ }^{2,10}$ In the $\mathrm{O}-\mathrm{N}-\mathrm{X}$ group of anomeric amides the $\mathrm{N}-\mathrm{X}$ bond should be elongated and destabilized and N-OAlk bond should be shortened due to $n_{\mathrm{O}(\mathrm{Alk})} \rightarrow \sigma_{\mathrm{N}-\mathrm{X}}^{*}$ anomeric effect action. $^{2-9}$

The high IR $v$ values of $\mathrm{C}=\mathrm{O}$ group in most of such amides was recognized as the argument for their nitrogen pyramidality, ${ }^{2,6}$ which was later confirmed by XRD studies. ${ }^{9-15}$ However, XRD evidence for the case of $N$-chloro- $N$-alkoxybenzamides was lacking because of their lability.

Herein, we have fulfilled XRD study of $N$-chloro- $N$-methoxy4-nitrobenzamide which was synthesized by the chlorination of $N$-methoxy-4-nitrobenzamide (Scheme 1 ). ${ }^{\ddagger}$ In fact, the investiga-

$\uparrow$ Geminal Systems. Part 62. For the previous communication, see ref. 1.

* N-Methoxy-4-nitrobenzamide 1. 4-Nitrobenzoyl chloride (1.573 g, $8.925 \mathrm{mmol})$ was added to the solution of methoxyamine $(0.270 \mathrm{~g}$, $8.925 \mathrm{mmol}$ ) and 2,6-dimethylpyridine ( $0.956 \mathrm{~g}, 8.925 \mathrm{mmol})$ in $\mathrm{MeCN}$ $(10 \mathrm{ml})$ at $-22{ }^{\circ} \mathrm{C}$, the reaction mixture was heated to $20^{\circ} \mathrm{C}$ within $21 \mathrm{~h}$ and kept at $20^{\circ} \mathrm{C}$ for 5 days, then it was evaporated in vacuo. The residue was washed with water $(15 \mathrm{ml})$, dried in vacuo at 1 Torr, yielding $1.491 \mathrm{~g}$ (85\%) of amide 1, yellow-white crystals, mp $176-179^{\circ} \mathrm{C}\left(\mathrm{CHCl}_{3}\right) .{ }^{1} \mathrm{H} \mathrm{NMR}$ $\left(500 \mathrm{MHz}\right.$, DMSO- $\left.d_{6}\right) \delta: 3.75(\mathrm{~s}, 3 \mathrm{H}, \mathrm{OMe}), 7.99\left(\mathrm{~d}, 2 \mathrm{H}, \mathrm{C}^{2} \mathrm{H}, \mathrm{C}^{6} \mathrm{H}\right.$, ${ }^{3} J 10.8 \mathrm{~Hz}$ ), 8.32 (d, $\left.2 \mathrm{H}, \mathrm{C}^{3} \mathrm{H}, \mathrm{C}^{5} \mathrm{H},{ }^{3} J 10.8 \mathrm{~Hz}\right), 12.09$ (br. s, $\left.1 \mathrm{H}, \mathrm{NH}\right)$. Found (\%): $\mathrm{N}, 14.02$. Calc. for $\mathrm{C}_{8} \mathrm{H}_{8} \mathrm{~N}_{2} \mathrm{O}_{4}(\%)$ : N, 14.28 .

$\mathrm{N}$-Chloro-N-methoxy-4-nitrobenzamide 2. The solution of $\mathrm{Bu}^{\mathrm{t}} \mathrm{OCl}$ (0.455 g, $4.191 \mathrm{mmol})$ in $\mathrm{CH}_{2} \mathrm{Cl}_{2}(2 \mathrm{ml})$ was added to the mixture of $\mathrm{N}$-methoxy-4-nitrobenzamide $\mathbf{1}(0.154 \mathrm{~g}, 0.785 \mathrm{mmol})$ and $\mathrm{CH}_{2} \mathrm{Cl}_{2}(5 \mathrm{ml})$ at $-25^{\circ} \mathrm{C}$. The reaction mixture was kept at $5{ }^{\circ} \mathrm{C}$ for $2.5 \mathrm{~h}$, then it was evaporated in vacuo. The residue was dissolved in $\mathrm{CH}_{2} \mathrm{Cl}_{2}(2 \mathrm{ml})$, and then hexane $(8 \mathrm{ml})$ was added. After keeping at $5{ }^{\circ} \mathrm{C}$ the precipitate thus formed was filtered off, dried in vacuo, yielding $0.142 \mathrm{~g} \mathrm{(78 \% )} \mathrm{of} \mathrm{amide} 2$, white crystals, mp $93-95^{\circ} \mathrm{C}$ (decomp.). ${ }^{1} \mathrm{H}$ NMR $\left(500 \mathrm{MHz}, \mathrm{CDCl}_{3}\right) \delta$ : 3.908 (s, 3 H, OMe), 7.933 (d, 2 H, C $\left.{ }^{2} \mathrm{H}, \mathrm{C}^{6} \mathrm{H},{ }^{3} J 9.5 \mathrm{~Hz}\right), 8.333(\mathrm{~d}, 2 \mathrm{H}$, $\left.\mathrm{C}^{3} \mathrm{H}, \mathrm{C}^{5} \mathrm{H},{ }^{3} J 9.5 \mathrm{~Hz}\right)$. MS (FAB): $233[\mathrm{M}+\mathrm{H}]^{+}(7.5), 231[\mathrm{M}+\mathrm{H}]^{+}(22.5)$, 197 (100).

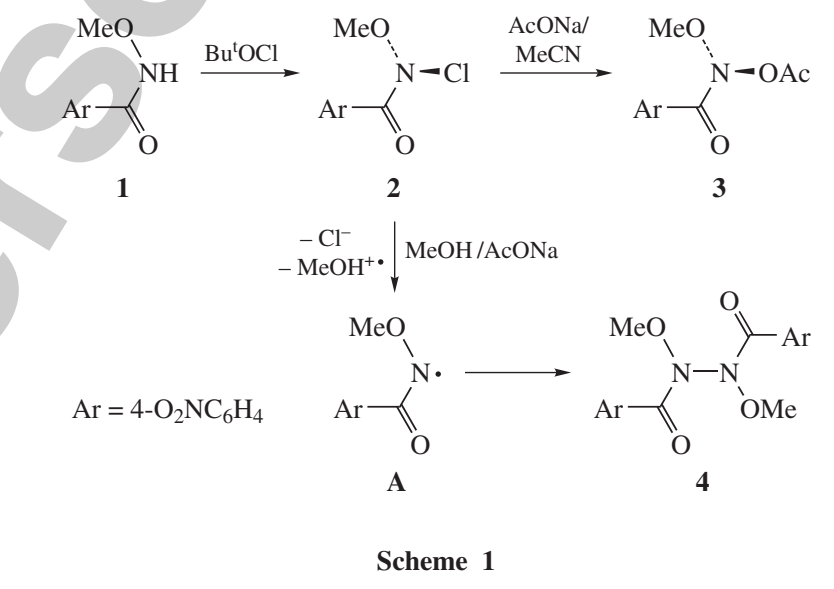

N-Acetoxy-N-methoxy-4-nitrobenzamide 3. The solution of amide 2 $(0.198 \mathrm{~g}, 0.856 \mathrm{mmol})$ in $\mathrm{MeCN}(15 \mathrm{ml})$ and AcONa $(0.246 \mathrm{~g}, 3.00 \mathrm{mmol})$ was stirred at $18-20^{\circ} \mathrm{C}$ for $32 \mathrm{~h}$. Then $\mathrm{CH}_{2} \mathrm{Cl}_{2}(8 \mathrm{ml})$ was added, the precipitate was filtered off, washed with $\mathrm{CH}_{2} \mathrm{Cl}_{2}(6 \mathrm{ml})$. The combined filtrate was evaporated in vacuo, the residue was extracted with $\mathrm{CH}_{2} \mathrm{Cl}_{2}$ (8 $\mathrm{ml})$, the extract was evaporated in vacuo, yielding $0.205 \mathrm{~g}(94 \%)$ of amide 3, firstly as viscous oil, which then converted into colourless crystals, mp $65-67^{\circ} \mathrm{C}\left(\mathrm{CH}_{2} \mathrm{Cl}_{2}-\mathrm{C}_{6} \mathrm{H}_{14}\right) .{ }^{1} \mathrm{H} \mathrm{NMR}\left(500 \mathrm{MHz}, \mathrm{CDCl}_{3}\right) \delta$ : 2.175 (s, 3 H, NOAc), 3.966 (s, 3 H, NOMe), 7.937 (d, 2 H, C ${ }^{2} \mathrm{H}, \mathrm{C}^{6} \mathrm{H}$, $\left.{ }^{3} J 9.5 \mathrm{~Hz}\right), 8.316\left(\mathrm{~d}, 2 \mathrm{H}, \mathrm{C}^{3} \mathrm{H}, \mathrm{C}^{5} \mathrm{H},{ }^{3} \mathrm{~J} 9.5 \mathrm{~Hz}\right)$. MS $\left(\mathrm{FAB}, \mathrm{H}^{+}\right): 255$ $[\mathrm{M}+\mathrm{H}]^{+}(2.5), 213(5.5), 195\left[\mathrm{M}-\mathrm{AcO}^{+}(18), 150(100) . \mathrm{MS}\left(\mathrm{FAB}, \mathrm{K}^{+}\right)\right.$: $293[\mathrm{M}+\mathrm{K}]^{+}(12), 195[\mathrm{M}-\mathrm{AcO}]^{+}(19), 150(100)$. Found $(\%): \mathrm{N}, 10.85$. Calc. for $\mathrm{C}_{10} \mathrm{H}_{10} \mathrm{~N}_{2} \mathrm{O}_{6}(\%)$ : N, 11.02 .

$\mathrm{N}, \mathrm{N}^{\prime}$-Bis(4-nitrobenzoyl)-N,N'-dimethoxyhydrazine 4. The solution of $N$-chloro- $N$-methoxy-4-nitrobenzamide $2(0.086 \mathrm{~g}, 0.373 \mathrm{mmol})$ in THF $(2 \mathrm{ml})$ was added to the solution of AcONa $(0.100 \mathrm{~g}, 1.220 \mathrm{mmol})$ in $\mathrm{MeOH}(10 \mathrm{ml})$ at $-23^{\circ} \mathrm{C}$, the reaction mixture was heated to $20^{\circ} \mathrm{C}$ within $24 \mathrm{~h}, \mathrm{MeOH}$ was evaporated in vacuo, the residue was extracted with $\mathrm{CH}_{2} \mathrm{Cl}_{2}(15 \mathrm{ml})$. The extract was evaporated in vacuo yielding $0.072 \mathrm{~g}$ $(99 \%)$ of the product 4 , white crystals, mp $86-88^{\circ} \mathrm{C}$ (decomp.). ${ }^{1} \mathrm{H}$ NMR $\left(500 \mathrm{MHz}, \mathrm{CDCl}_{3}\right) \delta: 4.001(\mathrm{~s}, 6 \mathrm{H}, \mathrm{NOMe}), 8.233\left(\mathrm{~d}, 4 \mathrm{H}, \mathrm{C}^{2} \mathrm{H}, \mathrm{C}^{6} \mathrm{H}\right.$, $\left.{ }^{3} J 9.0 \mathrm{~Hz}\right), 8.311\left(\mathrm{~d}, 4 \mathrm{H}, \mathrm{C}^{3} \mathrm{H}, \mathrm{C}^{5} \mathrm{H},{ }^{3} J 9.0 \mathrm{~Hz}\right)$. MS $\left(\mathrm{FAB}, \mathrm{H}^{+}\right): 391$ $[\mathrm{M}+\mathrm{H}]^{+}(7), 55(100) . \mathrm{MS}\left(\mathrm{FAB}, \mathrm{K}^{+}\right): 429[\mathrm{M}+\mathrm{K}]^{+}(19.5), 192$ (100). Found (\%): N, 14.20. Calc. for $\mathrm{C}_{16} \mathrm{H}_{14} \mathrm{~N}_{4} \mathrm{O}_{8}(\%)$ : N, 14.35 . 


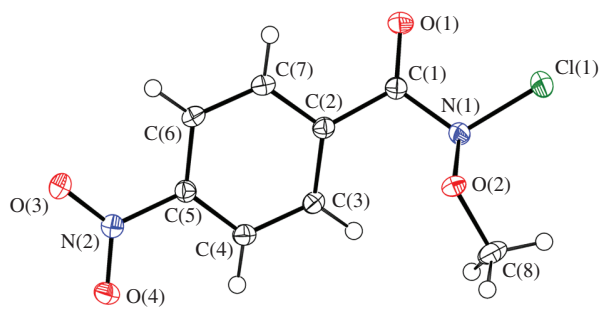

Figure 1 Molecular structure of compound 2. Selected bond lengths $(\AA)$ and bond angles $\left({ }^{\circ}\right)$ : $\mathrm{Cl}(1)-\mathrm{N}(1) 1.7288(14), \mathrm{O}(2)-\mathrm{N}(1) 1.3967(17), \mathrm{N}(1)-\mathrm{C}(1)$ 1.408(2), O(1)-C(1) 1.2046(19), C(1)-C(2) 1.490(2); O(2)-N(1)-C(1) 112.76(12), O(2)-N(1)-Cl(1) 110.84(10), C(1)-N(1)-Cl(1) 113.89(10).

tions done confirmed amide N(1) nitrogen pyramidal configuration (Figure 1). The sum of bond angles centered at this nitrogen atom $(\Sigma \beta)$ is $337.5(3)^{\circ}$, the deviation of $N(1)$ atom from the plane of bonded with $\mathrm{N}(1)$ atoms $\left(h_{\mathrm{N}}\right)$ is equal to $0.418(2) \AA$ (for $N$-methoxy-4-nitrobenzamide $1 \Sigma \beta$ is $354^{\circ}$ as shown by the reference XRD study).

Thus, in compound $\mathbf{2}$ the nitrogen pyramidality degree is lower in comparison with that in $N$-chloro- $N$-methoxyurea ${ }^{12}\left[\Sigma \beta=329.0(2)^{\circ}\right.$, $\left.h_{\mathrm{N}}=0.500(1) \AA\right]$. Probably this is caused by the bigger degree of conjugation of Lp of $\mathrm{N}(1)$ atom with aroyl group in 2 , than that takes place with carbamoyl group in $N$-chloro- $N$-methoxyurea. This conjugation increases $p$ character of $\mathrm{Lp}(\mathrm{N} 1)$ and shortened $\mathrm{Cl}(1)-\mathrm{N}(1)$ bond to $1.7288(14) \AA$. In $N$-chloro- $N$-methoxyurea the $\mathrm{N}-\mathrm{Cl}$ bond is longer [1.7563(11) $\AA^{12}$ ], but in substituted $\mathrm{N}$-chloro- $\mathrm{N}$-(phenyl)acetamides the $\mathrm{N}-\mathrm{Cl}$ bond is somewhat shorter (1.71-1.72 $\AA$ ). ${ }^{16}$ The N-OMe bond lengths in amide 2 [1.3967(17) $\AA$ ] and in $N$-chloro- $N$-methoxyurea [1.3984(13) $\mathrm{A}]^{12}$ are similar to those in $\mathrm{N}$-methoxy- $\mathrm{N}, \mathrm{N}$-bis(methoxycarbonyl)imide [1.396(1) $\AA]^{13}$ and in compound 1 [1.394(5) $\left.\AA\right]$. In the latter, the amide nitrogen atom has planar configuration as $s p^{2}$ hybridized one. In amide 2 strong pyramidal N(1) atom is $s p^{3}$ hybridized as it was predicted earlier. ${ }^{2}$ The length of $\mathrm{N}_{s p^{3}}-\mathrm{OMe}$ bond may be equal to that of $\mathrm{N}_{s p^{2}}-\mathrm{OMe}$ bond only if the former bond is additionally shortened. Evidently this shortening of $\mathrm{N}_{s p^{3}}-\mathrm{OMe}$ bond in amide 2 is caused by $n_{\mathrm{O}(\mathrm{Me})} \rightarrow \sigma_{\mathrm{N}-\mathrm{Cl}}^{*}$ anomeric effect action.

In compound 2 the amide $\mathrm{N}(1)-\mathrm{C}(1)$ bond is shorter [1.408(2) $\AA$ ] than proper amide $\mathrm{N}-\mathrm{C}$ bond in $\mathrm{N}$-acyloxy- $\mathrm{N}$-alkoxybenzamides ${ }^{6}$ (1.4394-1.4414 $\left.\AA, \Sigma \beta=323.51^{\circ}, 324.14^{\circ}\right)$ and in $N, N$-dialkoxybenzamides $^{9,10}[1.45 \AA$ in $N$-ethoxy- $N$-methoxy-4-nitrobenzamide and $1.42 \AA$ in $N$-methoxy- $N$-(4-nitrobenzyloxy)benzamide]. In methyl $N$-(4-chlorobenzoyloxy)- $N$-methoxycarbamate the amide $\mathrm{N}-\mathrm{C}$ bond is longer as well, ${ }^{11} 1.423(2) \AA\left(\Sigma \beta\right.$ is $334.1^{\circ}, h_{\mathrm{N}}$ is $0.426 \AA$ ). Shortening amide $\mathrm{N}-\mathrm{C}$ bond in amide 2 compared with $\mathrm{N}-\mathrm{C}$ bond in $\mathrm{N}$-acyloxy- $\mathrm{N}$-alkoxybenzamides, ${ }^{6} \mathrm{~N}, \mathrm{~N}$-dialkoxybenzamides ${ }^{9}$ and $N$-acyloxy- $N$-alkoxycarbamates ${ }^{11}$ may resulted from decrease in the N(1) nitrogen pyramidality degree. However, in amide $\mathbf{1}$, containing the almost planar amide nitrogen atom, the proper N-C bond is substantially shorter $[1.319(5) \AA]$ compared with the $\mathrm{N}(1)-\mathrm{C}(1)$ bond of compound 2 .

In amide 2 the $\mathrm{Lp}(\mathrm{N} 1)$ is oriented perpendicular to the carbonyl group plane [the $\mathrm{Lp}(\mathrm{N} 1)-\mathrm{N}(1)-\mathrm{C}(1)-\mathrm{O}(1)$ torsion angle is $-100^{\circ}$. The methyl group has $s c$-orientation toward $\mathrm{Lp}(\mathrm{N} 1)$ [the $\mathrm{Lp}(\mathrm{N} 1)-\mathrm{N}(1)-\mathrm{O}(2)-\mathrm{C}(8)$ torsion angle is $31^{\circ}$ ], whereas the aryl group is slightly turned round to the carbonyl group plane [the $\mathrm{O}(1)-\mathrm{C}(1)-\mathrm{C}(2)-\mathrm{C}(7)$ torsion angle is $\left.-30.4(2)^{\circ}\right]$. The nitro group is situated in the aryl substituent plane [the $\mathrm{O}(3)-\mathrm{N}(2)-\mathrm{C}(5)-\mathrm{C}(6)$ torsion angle is $3.7(2)^{\circ}$ ].

As other $N$-chloro- $N$-alkoxybenzamides ${ }^{17}$ compound 2 reacts with $\mathrm{AcONa}$ in $\mathrm{MeCN}$ selectively yielding $\mathrm{N}$-acetoxy- $\mathrm{N}$-methoxy4-nitrobenzamide 3 by nucleophilic substitution at amide nitrogen (see Scheme 1). Surprisingly, its methanolysis in the presence of AcONa afforded only $N, N^{\prime}$-bis(4-nitrobenzoyl)- $N, N^{\prime}$-dimethoxyhydrazine 4 . Apparently, reduction of compound 2 by SET-mech-

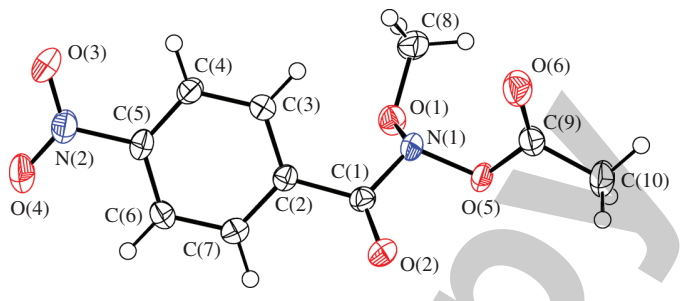

Figure 2 Molecular structure of compound 3. Selected bond lengths $(\AA)$ and bond angles $\left({ }^{\circ}\right)$ : $\mathrm{O}(1)-\mathrm{N}(1) 1.3970(18), \mathrm{O}(5)-\mathrm{N}(1)$ 1.4214(16), $\mathrm{O}(2)-\mathrm{C}(1)$ 1.2035(18), N(1)-C(1) 1.4113(19), O(6)-C(9) 1.1863(19), C(1)-C(2) 1.493(2); $\mathrm{O}(1)-\mathrm{N}(1)-\mathrm{O}(5)$ 107.99(11), O(1)-N(1)-C(1) 112.04(13), C(1)-N(1)-O(5) $110.26(11)$.

anism produces aminyl radical $\mathbf{A}$ which then gives dimer $\mathbf{4}$. In the same manner, $N$-chloro- $N$-methoxy- $N$-tert-alkylamines yield azoxy compounds by alcoholysis in the presence of $\mathrm{Et}_{3} \mathrm{~N}^{18}$ and in reactions with some amines. ${ }^{19}$ Analogously, methyl $N$-chloro$N$-methoxycarbamate yields $N, N^{\prime}$-bis(methoxycarbonyl)- $N, N^{\prime}$ dimethoxyhydrazine during methanolysis. ${ }^{20,21}$ This duality of chemical properties of amide 2 towards the nucleophiles is similar to that of $N$-chloro- $N$-alkoxycarbamates. ${ }^{17,20,21}$

The structure of $N$-acetoxy- $N$-methoxy-4-nitrobenzamide $3^{\S}$ has been investigated by XRD study (Figure 2). The amide $\mathrm{N}(1)$ atom has large pyramidality degree $\left[\Sigma \beta=330.29^{\circ}, h_{\mathrm{N}}=\right.$ $=0.4550(15) \AA]$ which is more compared with that in amide 2 , but less than that in the known $N$-acyloxy- $N$-alkoxybenzamides. ${ }^{6}$ Probably, the last decrease in pyramidality degree is caused by the action of the 4-nitro group ( $c f$. ref. 6)

The $\mathrm{O}(1)-\mathrm{N}(1)$ bond $[1.3970(18) \AA]$ is shorter than the $\mathrm{O}(5)-\mathrm{N}(1)$ bond $[1.4214(16) \AA]$ due to $n_{\mathrm{O}(\mathrm{Me})} \rightarrow \sigma_{\mathrm{N}-\mathrm{O}(\mathrm{Ac})}^{*}$ anomeric effect action. This $\mathrm{O}(1)-\mathrm{N}(1)$ bond length is similar to $\mathrm{N}-\mathrm{OMe}$ bond lengths in amide 2, $N$-acetoxy- $N$-methoxyurea ${ }^{13}$ and $N$-methoxy- $N, N$-bis(methoxycarbonyl)imide. ${ }^{13}$ However, in $N$-benzoyloxy- $N$-benzyloxybenzamides these differences between lengths of $\mathrm{N}-\mathrm{OC}(\mathrm{O}) \mathrm{R}$ bond and $\mathrm{N}-\mathrm{OAlk}$ bond are larger. ${ }^{6}$ In the case of amide 3 the presence of 4-nitrobenzoyl group at N(1) atom reduces the action of the $n_{\mathrm{O}(\mathrm{Alk})} \rightarrow \sigma_{\mathrm{N}-\mathrm{OC}(\mathrm{O}) \mathrm{R}}^{*}$ anomeric effect.

The amide $\mathrm{N}(1)-\mathrm{C}(1)$ bond in 3 is longer [1.4113(19) $\AA$ ] than that bond in compound 2 . The $\mathrm{O}(5)-\mathrm{C}(9)$ bond is $s p$-oriented

$\S$ Crystal data for 1: crystals were grown from $\mathrm{CH}_{2} \mathrm{Cl}_{2}$ at $-20^{\circ} \mathrm{C}$, $\mathrm{C}_{8} \mathrm{H}_{8} \mathrm{~N}_{2} \mathrm{O}_{4}$, monoclinic, space group $P c, a=3.8578(5), b=11.8168(16)$ and $c=9.6848(12) \AA, \beta=100.297(11)^{\circ}, V=434.38(9) \AA^{3}, F(000)=204$, $d_{\text {calc }}=1.500 \mathrm{~g} \mathrm{~cm}^{-3}, Z=2, \mu=0.123 \mathrm{~mm}^{-1}, M=196.16$.

Crystal data for 2: crystals were grown from $\mathrm{CH}_{2} \mathrm{Cl}_{2}$ at $-20{ }^{\circ} \mathrm{C}$, $\mathrm{C}_{8} \mathrm{H}_{7} \mathrm{~N}_{2} \mathrm{O}_{4} \mathrm{Cl}$, triclinic, space group $P \overline{1}, a=6.7596(4), b=7.8452(6)$ and $c=9.6412(6) \AA, \alpha=72.614(6)^{\circ}, \beta=84.737(5)^{\circ}, \gamma=73.358(6)^{\circ}, V=$ $=467.47(5) \AA^{3}, F(000)=236, d_{\text {calc }}=1.638 \mathrm{~g} \mathrm{~cm}^{-3}, Z=4, \mu=0.404 \mathrm{~mm}^{-1}$, $M=230.61$.

Crystal data for 3 : crystals were grown from $\mathrm{CH}_{2} \mathrm{Cl}_{2}-\mathrm{C}_{6} \mathrm{H}_{14}$ at $-20^{\circ} \mathrm{C}$, $\mathrm{C}_{10} \mathrm{H}_{10} \mathrm{~N}_{2} \mathrm{O}_{6}$, triclinic, space group $P \overline{1}, a=6.2863(4), b=8.7528(7)$ and $c=11.5095(8) \AA, \alpha=68.848(7)^{\circ}, \beta=84.283(6)^{\circ}, \gamma=75.474(6)^{\circ}, V=$ $=571.71(7) \AA^{3}, F(000)=264, d_{\text {calc }}=1.477 \mathrm{~g} \mathrm{~cm}^{-3}, Z=2, \mu=0.124 \mathrm{~mm}^{-1}$, $M=254.20$.

Data were measured using an Xcalibur 3 diffractometer $[T=100 \mathrm{~K}$ (1 and 2$), 180 \mathrm{~K}(3)$, graphite-monochromated MoK $\alpha$ radiation, $2 \theta / \theta \mathrm{scan}$, $\left.2 \theta_{\max }=58.04^{\circ}(\mathbf{1}), 65.4^{\circ}(\mathbf{2}), 57.72^{\circ}(\mathbf{3})\right]$. The structures were solved by direct method using the SHELXTL PLUS program package. ${ }^{22}$ Refinement against $F^{2}$ in an anisotropic approximation (the hydrogen atoms isotropic in the riding model) by a full matrix least-squares method for 1195 reflections was carried out to $w R_{2}=0.106\left[R_{1}=0.054\right.$ for 969 reflections with $F>4 \sigma(F), \mathrm{S}=1.06]$ for $\mathbf{1}$, for 3069 reflections was carried out to $w R_{2}=0.112\left[R_{1}=0.042\right.$ for 2597 reflections with $\left.F>4 \sigma(F), S=1.08\right]$ for 2 , and for 2588 reflections was carried out to $w R_{2}=0.095\left[R_{1}=0.045\right.$ for 1713 reflections with $F>4 \sigma(F), S=0.99$ ] for 3 .

CCDC 857730-857732 contain the supplementary crystallographic data for this paper. These data can be obtained free of charge from The Cambridge Crystallographic Data Centre via www.ccdc.cam.ac.uk/data_request/cif. For details, see 'Notice to Authors', Mendeleev Commun., Issue 1, 2012. 
towards $\mathrm{Lp}(\mathrm{N} 1)$ [the $\mathrm{Lp}(\mathrm{N} 1)-\mathrm{N}(1)-\mathrm{O}(5)-\mathrm{C}(9)$ torsion angle is $-2^{\circ}$ ], whereas the $\mathrm{C}(9)-\mathrm{O}(6)$ carbonyl has $s p$-orientation towards $\mathrm{N}(1)-\mathrm{O}(5)$ bond [the $\mathrm{O}(6)-\mathrm{C}(9)-\mathrm{O}(5)-\mathrm{N}(1)$ torsion angle is $\left.-3.4(4)^{\circ}\right]$. As in compound 2 , the $\mathrm{O}(1)-\mathrm{C}(8)$ bond is $s p$-oriented towards $\mathrm{Lp}(\mathrm{N} 1)$ [the $\mathrm{Lp}(\mathrm{N} 1)-\mathrm{N}(1)-\mathrm{O}(1)-\mathrm{C}(8)$ torsion angle is $26^{\circ}$ ]. The $\mathrm{C}(1)=\mathrm{O}(2)$ carbonyl group has perpendicular orientation towards $\mathrm{Lp}(\mathrm{N} 1)$ [the $\mathrm{Lp}(\mathrm{N} 1)-\mathrm{N}(1)-\mathrm{C}(1)-\mathrm{O}(2)$ torsion angle is $-100^{\circ}$. The aryl group is some turned round to the $\mathrm{C}(1)=\mathrm{O}(2)$ carbonyl group [the $\mathrm{O}(2)-\mathrm{C}(1)-\mathrm{C}(2)-\mathrm{C}(7)$ torsion angle is $\left.-41.7(2)^{\circ}\right]$.

To sum up, XRD study of a representative of $N$-chloro- $N$-alkoxybenzamide confirmed the high degree of pyramidality of its amide nitrogen atom. The influence of electron-withdrawing 4-nitro substituent in benzoyl group of $N$-chloro- $N$-alkoxybenzamides and $N$-acyloxy- $N$-alkoxybenzamides on their structure parameters and chemical properties has been demonstrated.

\section{References}

1 V. G. Shtamburg, A. V. Tsygankov, O. V. Shishkin, R. I. Zubatyuk, V. V. Shtamburg, M. V. Gerasimenko, A. V. Mazepa and R. G. Kostyanovsky, Mendeleev Commun., 2012, 22, 92.

2 S. A. Glover, Tetrahedron, 1998, 54, 7229.

3 R. G. Gerdes, S. A. Glover, J. F. ten Have and C. A. Rowbottom, Tetrahedron Lett., 1989, 30, 2649.

4 A. Rauk and S. A. Glover, J. Org. Chem., 1996, 61, 2337.

5 S. A. Glover and A. Rauk, J. Org. Chem., 1999, 64, 2340.

6 A.-M. E. Gillson, S. A. Glover, D. J. Tucker and P. Turner, Org. Biomol. Chem., 2003, 1, 3430.

7 S. A. Glover, A. Rauk, J. M. Buccigross, J. J. Campbell, G. P. Hammond, G. Mo, L. E. Andrews and A.-M. E. Gillson, Can. J. Chem., 2005, 83, 1492.

8 K. L. Cavanagh, S. A. Glover, H. L. Price and R. R. Schumacher, Aust. J. Chem., 2009, 62, 700.

9 K. M. Digianantonio, S. A. Glover, J. P. Johns and A. A. Rosser, Biomol. Chem., 2011, 9, 4116.
10 S. A. Glover, J. M. White, A. A. Rosser and K. M. Digianantonio, J. Org. Chem., 2011, 76, 9757.

11 O. V. Shishkin, R. I. Zubatyuk, V. G. Shtamburg, A. V. Tsygankov, E. A Klots, A. V. Mazepa and R. G. Kostyanovsky, Mendeleev Commun., 2006, 222.

12 V. G. Shtamburg, O. V. Shishkin, R. I. Zubatyuk, S. V. Kravchenko, A. V. Tsygankov, A. V. Mazepa, E. A. Klots and R. G. Kostyanovsky, Mendeleev Commun., 2006, 323.

13 O. V. Shishkin, V. G. Shtamburg, R. I. Zubatyuk, D. A. Olefir, A. V. Tsygankov, A. V. Prosyanik, A. V. Mazepa and R. G. Kostyanovsky, Chirality, 2009, 21, 642.

14 V. G. Shtamburg, O. V. Shishkin, R. I. Zubatyuk, S. V. Kravchenko, A. V. Tsygankov, V. V. Shtamburg, V. B. Distanov and R. G. Kostyanovsky, Mendeleev Commun., 2007, 17, 178.

15 V. G. Shtamburg, A. V. Tsygankov, M. V. Gerasimenko, O. V. Shishkin, R. I. Zubatyuk, A. V. Mazepa and R. G. Kostyanovsky, Mendeleev Commun., 2011, 21, 50 .

16 S.-Q. Dou, B. T. Gowda, H. Paulus and A. Weiss, Z. Naturforsch., A: Phys. Sci., 1994, 49, 1136.

17 V. G. Shtamburg, E. A. Klots, A. P. Pleshkova, V. I. Avramenko, S. P. Ivonin, A. V. Tsygankov and R. G. Kostyanovsky, Izv. Akad. Nauk, Ser. Khim., 2003, 2132 (Russ. Chem. Bull., Int. Ed., 2003, 52, 2251).

18 R. G. Kostyanovsky, V. F. Rudchenko, V. G. Shtamburg, I. I. Chervin and Sh. S. Nasibov, Tetrahedron, 1981, 37, 4245.

19 V. G. Shtamburg, V. F. Rudchenko, Sh. S. Nasibov, I. I. Chervin and R. G. Kostyanovsky, Izv. Akad. Nauk SSSR, Ser. Khim., 1981, 2327 (Bull. Acad. Sci. USSR, Div. Chem. Sci., 1981, 30, 1914).

20 V. G. Shtamburg, V. F. Rudchenko, Sh. S. Nasibov, I. I. Chervin and R. G. Kostyanovsky, Izv. Akad. Nauk SSSR, Ser. Khim., 1981, 449 (Bull. Acad. Sci. USSR, Div. Chem. Sci., 1981, 30, 423).

21 V. G. Shtamburg, V. M. Grinev, E. A. Klots and A. V. Tsygankov, Visnyk Dnipropetrovsk. Univ., Ser. Khimiya, 2005, 11, no. 7, 104 (in Russian).

22 G. M. Sheldrick, Acta Crystallogr., 2008, A64, 112.

Received: 16th December 2011; Com. 11/3850 